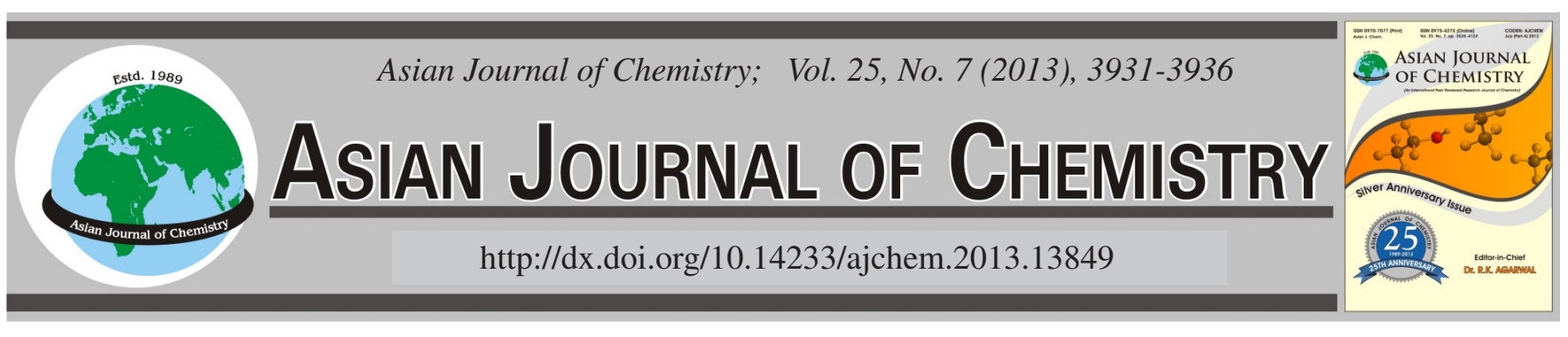

\title{
Pesticide Residues Analysis in Human Milk Samples in Isparta Region (Turkey)
}

\author{
H. SeÇILMis CANBaY ${ }^{1, *}$, S. ÖGÜT ${ }^{2}$, M. YILMAZER ${ }^{3}$ and R.S. ÜnSAL ${ }^{4}$
}

${ }^{1}$ Research and Practice Center, Mehmet Akif Ersoy University, 15100 Burdur, Turkey

${ }^{2}$ Food Engineering Department, Engineering and Architecture Faculty, Süleyman Demirel University, 32260, Isparta, Turkey

${ }^{3}$ Experimental and Observational Student Research and Practice Center, Süleyman Demirel University, 32260 Isparta, Turkey

${ }^{4}$ Isparta Family Health Center 32200, Isparta, Turkey

*Corresponding author: Fax: +90 248 2132154; Tel: +90 248 2133244; E-mail: halecanbay@ gmail.com

\begin{abstract}
Breast milk monitoring studies are extremely important, because they concern for possible adverse health effects for suckling infants and constitute a biomarker of environmental exposure to pesticides residues. The present study reports 15 pesticides levels in human breast milk in Isparta, Turkey. Human milk samples were collected in Isparta between October 2009 and May 2010. Human milk samples were taken from 101 healthy women. Different extraction solvent mixtures were compared for the analysis of pesticides in human milk. GC/ ECD and GC/NPD were employed for the identification of different pesticides. The samples were obtained by family health center in Isparta. Liquid-liquid extraction procedure chloroform $/ n$-hexane $(2: 1, \mathrm{v} / \mathrm{v})$ and dichloromethane $/ n$-hexane $(2: 1$, v/v) were used. The detection limits were between $0.04-0.027 \mathrm{ng} / \mathrm{g}$ lipid for the studied pesticides, recoveries ranged from 89.26 to $101.10 \%$ in samples and the relative standard deviations were in the range 1 to $10 \%$. Endosulfan was measured only in 3 samples and mean concentration of endosulfan was $0.190 \mathrm{ng} / \mathrm{g}$ lipid. Dichlorvos was measured only in 5 samples and mean concentration of dichlorvos was $0.188 \mathrm{ng} / \mathrm{g}$ lipid.
\end{abstract}

Key Words: Gas chromatography, Human milk, Pesticide residue.

ᄂ $-\ldots-\ldots-\ldots-\ldots-\ldots-\ldots-\ldots-\ldots-\ldots-\ldots-\ldots$

\section{INTRODUCTION}

Humans are exposed to a mixture of many environmental pollution (pesticides, polychlorinated biphenyls, phthalates etc.). The use of pesticides is greatly increased and widespread in the world during the last 30 years ${ }^{1}$. Pesticides are used for agricultural aplications and daily chemical products (insect repellents, paints, glues, etc.). Pesticides can represent a potential risk to human beings.

Some studies have demonstrated the harmful effect of pesticides in human health, such as an increase of different symptoms including neuritis, psychiatric manifestations, hepatorenal dysfunction, electroencephalograph changes and neurological, immune, metabolic and endocrine problems. In addition, pesticides is related to an increase in the incidence of leukaemia and bladder cancer ${ }^{2-5}$.

Due to their widespread use, organochlorine pesticides and organophosphorus pesticides can be determined in all environmental and biological matrices (human milk, animal foodstuff, soil, vegatable, water). Organochlorine pesticides were produced in large amounts in the 1940-1950s and were banned or severely restricted, since the early 1970s in most of the developed countries. Organochlorine pesticides have been started to be used during 1960-1970s in Turkey and they have been severly restricted during the 1983. The lipophilic organochlorine pesticides persist in the enviromental for a long time. They have been confirmed to bioaccumulate in blood, breast milk and adipose tissues of humans through the food chain because of their relatively insolubility in water and high solubility in fat. It is well-known that organophosphorus pesticides are less stable and persistent than organochlorine pesticides $^{6,7}$. Organophosphorus pesticides have replaced the organochlorine pesticides and they are being used increasingly in agricultural aplications since the 1970s. They can also accumulate along the food chain. Therefore they can represent a potential risk to human health ${ }^{8,9}$. Also, some metabolites of these compounds have been found to be more toxic and persistent. Human milk contains a number of bioactive factors, proteins and hormones which may be relevant for optimal nutrition regulation of metabolic pathways and development of the infant ${ }^{10}$. Human milk provides many developmental, psychological, economic and practical advantages. Breast milk monitoring studies are extremely important, because they concern for possible adverse health effects for suckling infants and constitute a biomarker of environmental exposure to pesticides residues ${ }^{11}$. Breast milk is at the top of the food chain and may be one of the good environmental pollution indicator. 
Generally, the determination of pesticides in milk have been based on chromatographic methods, primary gas chromatography which are characterized by low limits of detection and high precision and sensitivity. Gas chromatography coupled with selective and sensitive detection methods such as electron-capture detection, nitrogen-phosphorous detection (NPD), photometric detection and by both electronic impact (EI) and positive chemical ionization (PCI) and negative chemical ionization mass -spectrometry (MS $)^{12-14}$.

Before the chromatographic measurement, appropriate sample pretreatments are generally required to clean up or preconcentrate the target species. Various extraction methods are currently used for pesticides in milk, including liquidliquid extraction and solid-phase extraction ${ }^{14-17}$.

In the present study, human breast milk samples were collected from the Isparta (Turkey) region. Isparta is a province in southwestern Turkey and situated in the Lakes Area of Mediterranean Region. It has an area of $8,993 \mathrm{~km}^{2}$. Its adjacent province are Afyon to the northwest, Burdur to the southwest, Antalya to the south and Konya to the east. The pillar of the economy is agricultural products (apples, sour cherries, grapes, roses and rose products). Organophosphate and synthetic pyrethroid pesticides are commonly used in Isparta region. There are few papers providing evidence of human exposure by reporting organochlorine pesticides contamination levels in human milk and adipose tissue from Turkey ${ }^{7,18-26}$. There are limitted data on levels of organophosphorus pesticides in human milk ${ }^{17}$ but no data about the levels of organophosphorus pesticides in breast milk from Turkey. Therefore, the values for Isparta province obtained in this study will play a crucial role in determining the general contamination of organochlorine pesticides and organophosphorus pesticides and are considered important in terms of providing baseline data from a different source of organochlorine pesticides and organophosphorus pesticides contamination in Turkey. The main aim of this study was determine the concentrations of persistent pesticides in human milk. Therefore, different extraction solvents were tried.

\section{EXPERIMENTAL}

Sample collection: Samples of human milk were collected from october 2009 to may 2010. One hundred one human milk samples of about $30 \mathrm{~mL}$ each were obtained from mothers living in the Isparta city center. Human milk samples were taken from one of the breasts by manual expression at the end of the feeding into the clean glass container. The collected milk samples were stored at $-20^{\circ} \mathrm{C}$ until the analysis.

Lipid determination was done on a separate aliquot of milk by extracting $2 \mathrm{~g}$ milk with $6 \mathrm{~mL}$ methanol/chloroform $(1: 2, \mathrm{v} / \mathrm{v})$ for $15 \mathrm{~min}$ into an ultrasonic bath (Bandelin Sonorex, Germany). The organic layer was then separated. The extraction was repeated using with $6 \mathrm{~mL}$ methanol/chloroform $(1: 2, \mathrm{v} / \mathrm{v})$ for 15 min into an ultrasonic bath. All the organic fractions were evaporated by rotary vacuum evaporation (Laborota 4001 , Germany) at $40^{\circ} \mathrm{C}$. Lipids were gravimetrically measured after keeping the sample at $105^{\circ} \mathrm{C}$ for $2 \mathrm{~h}$.

Dichlormethane (HPLC grade), acetone (analytical grade), methanol (HPLC grade), $n$-hexane (HPLC grade), chloroform (analytical grade) and toluene (HPLC grade) were obtained from Merck (Dermstadt, Germany). Diethyl ether and formic acid for pesticide residue analysis were purchased from Riedelde Haen (Seelze, Germany). Sodium chloride obtained from Merck (Dermstadt, Germany).

The chlorpyriphos, diazinon, parathion-methyl, methidathion, ethion, cypermethrin, deltamethrin, dichlorvos, malathion, $\alpha$-endosulfan, $\beta$-endosulfan DDD and DDE were obtained from Riedel-de Haen (Seelze, Germany). $o, p^{\prime}$-DDT was purchased from Dr. Ehrenstorfer (Augsburg, Germany). p,p'-DDT was purchased from Aldrich (Steinheim, Germany). Stock standard solutions of $100 \mathrm{mg} / \mathrm{mL}$ of each compound were prepared in toluen $/ n$-hexane and stored at $-20^{\circ} \mathrm{C}$. In both cases, different working standard solutions were prepared by dilution in the same solvent.

Analytical procedure:A Shimadzu GC-17A (Shimadzu, Japan) gas chromatograph was used for determination of diazinon, chlorpyriphos, parathion-methyl, ethion, methidathion, cypermethrin, deltamethrin, dichlorvos and malathion. It was equipped with a split-splitleless injector (AOC-20i, Shimadzu, Japan), a temperature programmer and nitrogen-phosphorus detector (Shimadzu, Japan) (GC/NPD) were used. Gas chromatograph was performed on TRB-5 (Teknokroma, Spain) fused silica capillary column $(30 \mathrm{~m} \times 0.32 \mathrm{~mm}, 0.25 \mathrm{~mm})$. The following conditions were used: carrier gas: helium $(2.0 \mathrm{~mL} /$ min, constant flow); splitless injection ( $1 \mathrm{~mL})$. The temperature program applied as follows: initial temperature $80{ }^{\circ} \mathrm{C}$, held for $1 \mathrm{~min}, 10^{\circ} \mathrm{C} / \mathrm{min}$ to $160^{\circ} \mathrm{C}$, held for $5 \mathrm{~min}$, then $3{ }^{\circ} \mathrm{C} / \mathrm{min}$ to $240{ }^{\circ} \mathrm{C}$, followed by $24^{\circ} \mathrm{C} / \mathrm{min}$ to $300^{\circ} \mathrm{C}$, held for $20 \mathrm{~min}$. The injector and detector were operated at $300^{\circ} \mathrm{C}$ and $300{ }^{\circ} \mathrm{C}$, respectively. Data handling was performed using GC Labsolutions software (Shimadzu, Japan).

A Perkin-Elmer Autosystem XL gas chromatograph (Perkin-Elmer, USA) was used for determination of DDE, $o, p^{\prime}-$ DDT, DDD, $p, p$-DDT, $\alpha$-endosulfan and $\beta$-endosulfan. It was fitted with an electron-capture detection system, an autosampler (Perkin-Elmer) and a split-splitless injector, equipped with a TC Nav WS (Perkin-Elmer) data system. A PE 1701, $30 \mathrm{~m} \times 0.32 \mathrm{~mm}$ i.d. capillary column with a $1.00 \mathrm{~mm}$ film (Perkin-Elmer, USA) was used in combination with the following oven temperature programme: initial temperature $100{ }^{\circ} \mathrm{C}$, held for $1 \mathrm{~min}, 30^{\circ} \mathrm{C} / \mathrm{min}$ ramp to $180^{\circ} \mathrm{C}$, held for $5 \mathrm{~min}$ then, $7^{\circ} \mathrm{C} / \mathrm{min}$ to $300^{\circ} \mathrm{C}$, held for $5 \mathrm{~min}$. The carrier gas (helium) flow rate was in constant flow mode at $2.0 \mathrm{~mL} / \mathrm{min}$. Splitless injection of a $1 \mathrm{ml}$ volume was carried out at $300^{\circ} \mathrm{C}$. Detector was operated at $300{ }^{\circ} \mathrm{C}$.

\section{Extraction of pesticides from the human milk}

Sample preperation (organophosphate and pyrethroid pesticides): For the extraction of pesticide residues in milk, liquid-liquid extraction method was used. All the samples were thawed, homogenized by vigorous shaking, weighed. $10 \mathrm{~mL}$ of the samples was placed in a 50-mL glass flask. After the addition of $2 \mathrm{~mL}$ formic acid, the extraction was performed with $30 \mathrm{~mL}$ of chloroform $/ n$-hexane $(2: 1, \mathrm{v} / \mathrm{v})$. The flasks were introduced into an ultrasonic bath (Bandelin Sonorex, Germany) and organic layer was then separated. The extraction was repeated using $30 \mathrm{~mL}$ chloroform $/ n$-hexane $(2: 1, \mathrm{v} / \mathrm{v})$.

All organic fractions were evaporated by rotary vacuum evaporation (Heidolph Laborota 4001 , Germany) at $40^{\circ} \mathrm{C}$ and 
the residue dissolved in $0.5 \mathrm{~mL}$ of toluene prior to injection into the gas chromatograph ${ }^{16,24}$.

Sample preperation (organochlorine pesticides): For the extraction of pesticide residues in milk, liquid-liquid extraction method was used. All samples were thawed, homogenized by vigorous shaking, weighed. $10 \mathrm{~mL}$ of the samples was placed in a 50-mL glass flask. After the addition of $2 \mathrm{~mL}$ formic acid, the extraction was performed with $30 \mathrm{~mL}$ of dichloromethane/n-hexane $(2: 1, \mathrm{v} / \mathrm{v})$. The flasks were introduced into an ultrasonic bath (Bandelin Sonorex, Germany) and organic layer was then separated. The extraction was repeated using $30 \mathrm{~mL}$ dichloromethane $/ n$-hexane $(2: 1, \mathrm{v} / \mathrm{v})$. And all organic fractions were evaporated by rotary vacuum evaporation (Laborota 4001 , Germany) at $40^{\circ} \mathrm{C}$ and the residue dissolved in $0.5 \mathrm{~mL}$ of $n$-hexane prior to injection into the gas chromatograph $^{16,24}$.

Statistical analyses: Statistical analyses were conducted using SPSS verion 15.0. Data are expressed as mean \pm SD or $\mathrm{n}(\%)$. Differences were considered significant at $p$ value $<$ 0.05 in all statistical tests used. Descriptive statistics (mean, standard deviation) were computed to characterize the distribution of pesticides concentrations in human milk samples analyzed. Limit of detection (LOD) and the limit of quantification (LOQ) were determined for every sample. We defined the LOD as three times the background noise of the chromatographic instrument. Samples with amount below the LOD were not detectable.

\section{RESULTS AND DISCUSSION}

Subjects' characteristics, including maternal age, socioeconomic status and smoking habit are shown in Table-1. The starting point for the comparasion of the different extraction solvents was in each case previously optimized to give the

\section{TABLE-1}

GENERAL DEMOGRAPHIC CHARACTERISTICS OF MOTHERS

\begin{tabular}{ll}
\hline $\mathrm{N}$ & 101 \\
Age (Year) & $27.8 \pm 7.60$ \\
Occupation & Housewife: $42.57 \%$; Other: $57.43 \%$ \\
Current smoker & $10.89 \%$ \\
Health problem & $12.87 \%$ \\
\hline
\end{tabular}

best recoveries for all the studied pesticide compounds. Tables 2 and 3 show the recovery results obtained using different solvent and solvent mixtures like dichloromethane, chloroform, chloroform $/ n$-hexane mixture, acetone $/ n$-hexane mixture, dichloromethane/acetone mixture among them, chloroform/ $n$-hexane $(2: 1, \mathrm{v} / \mathrm{v})$ mixture seems to be the best for nitrogenphosphorous detection analysis and dichloromethane $/ n$-hexane $(2: 1, v / v)$ mixture seems to be the best for electron-capture detection analysis. Nitrogen-phosphorous detection chromatogram for diazinon, chlorpyriphos, parathion-methyl, ethion, methidathion, cypermethrin, deltamethrin, dichlorvos and malathion of a human milk sample analyzed on TR5 column is shown in Fig. 1. Fig. 2a and $2 b$ reports the chromatograms of milk sample and spiked extracts of milk sample (NPD). Electron-capture detection chromatogram for $\alpha$-endosulfan, $\beta$-endosulfan, DDE, $o, p^{\prime}$-DDT, DDD, $p, p^{\prime}$-DDT of a human milk sample analyzed on PE 1701 column is shown in Fig. 3. Fig. $4 \mathrm{a}$ and $4 \mathrm{~b}$ reports the chromatograms of milk sample and spiked extracts of milk sample.

The pesticides determined by GC-NPD were eluted between 5 and $50 \mathrm{~min}$. For the $\alpha$-endosulfan, $\beta$-endosulfan, DDE, $o, p^{\prime}$-DDT, DDD and $p, p^{\prime}$-DDT analyzed by GC-ECD with retention times between 17 and $25 \mathrm{~min}$. GC-NPD chromatograms were very clean without interfering peaks in the areas of interest. Therefore, no clean-up step was necessary. Also, for the $\alpha$-endosulfan, $\beta$-endosulfan, DDE, $o, p^{\prime}$-DDT, DDD and

TABLE-2

TOTAL RECOVERY RESULTS (MEANS \pm SD \%) OBTAINED FOR MILK EXTRACTED USING DIFFERENT SOLVENT AND SOLVENT MIXTURES (NPD) (N=5)

\begin{tabular}{|c|c|c|c|c|c|c|}
\hline $\begin{array}{c}\text { Solvent/solvent } \\
\text { Mixture }\end{array}$ & Chloroform & Chloroform/methanol & $\begin{array}{c}\text { Chloroform/ } \\
n \text {-hexane }\end{array}$ & Dichlormethane & $\begin{array}{c}\text { Dichloromethane/ } \\
n \text {-hexane }\end{array}$ & $\begin{array}{c}\text { Dichloromethane/ } \\
\text { acetone }\end{array}$ \\
\hline Diazinon & $83.22 \pm 5.90$ & $89.10 \pm 5.85$ & $93.40 \pm 5.10$ & $70.30 \pm 6.90$ & $71.20 \pm 6.80$ & $86.10 \pm 5.75$ \\
\hline Chlorpyriphos & $93.24 \pm 5.40$ & $92.85 \pm 5.50$ & $99.57 \pm 4.20$ & $71.65 \pm 6.55$ & $71.00 \pm 6.45$ & $90.10 \pm 5.40$ \\
\hline Parathion-methyl & $113.51 \pm 6.00$ & $110.20 \pm 5.10$ & $101.10 \pm 4.60$ & $72.28 \pm 6.95$ & $71.25 \pm 6.75$ & $96.35 \pm 4.85$ \\
\hline Ethion & $94.18 \pm 5.10$ & $93.98 \pm 5.25$ & $96.20 \pm 4.85$ & $82.21 \pm 8.20$ & $69.78 \pm 8.35$ & $84.14 \pm 5.90$ \\
\hline Methidathion & $85.32 \pm 5.30$ & $85.00 \pm 5.00$ & $90.10 \pm 5.00$ & $65.35 \pm 8.25$ & $66.50 \pm 8.40$ & $83.40 \pm 5.95$ \\
\hline Cypermethrin & $82.20 \pm 7.20$ & $82.00 \pm 7.25$ & $89.26 \pm 6.90$ & $60.10 \pm 9.70$ & $61.25 \pm 9.95$ & $81.95 \pm 7.00$ \\
\hline Deltamethrin & $83.10 \pm 7.30$ & $82.50 \pm 7.25$ & $89.95 \pm 7.10$ & $60.25 \pm 9.95$ & $60.85 \pm 9.85$ & $82.86 \pm 7.15$ \\
\hline Dichlorvos & $91.10 \pm 5.55$ & $91.20 \pm 5.40$ & $93.10 \pm 5.30$ & $71.30 \pm 8.25$ & $71.90 \pm 8.10$ & $90.95 \pm 5.75$ \\
\hline Malathion & $90.25 \pm 5.40$ & $90.63 \pm 5.40$ & $92.28 \pm 4.30$ & $70.83 \pm 8.30$ & $70.50 \pm 8.05$ & $90.59 \pm 5.85$ \\
\hline
\end{tabular}

TABLE-3

TOTAL RECOVERY RESULTS (MEANS \pm SD \%) OBTAINED FOR MILK EXTRACTED USING DIFFERENT SOLVENT AND SOLVENT MIXTURES (ECD) $(\mathrm{N}=5)$

\begin{tabular}{|c|c|c|c|c|c|c|}
\hline Solvent/solvent mixture & $\mathrm{DDE}$ & $o, p^{\prime}$-DDT & DDD & $p, p^{\prime}$-DDT & $\alpha$-Endosulfan & $\beta$-Endosulfan \\
\hline Acetone $/ n$-hexane & $90.10 \pm 5.50$ & $89.02 \pm 5.75$ & $82.98 \pm 5.10$ & $87.65 \pm 6.00$ & $89.33 \pm 5.25$ & $90.91 \pm 5.30$ \\
\hline Dichloromethane/ $n$-hexane & $93.25 \pm 3.15$ & $90.10 \pm 3.45$ & $91.77 \pm 3.80$ & $89.75 \pm 3.00$ & $91.50 \pm 3.20$ & $91.20 \pm 3.40$ \\
\hline Diethyl ether/ $n$-hexane & $85.30 \pm 4.90$ & $85.25 \pm 5.20$ & $84.26 \pm 5.50$ & $89.35 \pm 5.45$ & $87.22 \pm 6.00$ & $88.36 \pm 5.85$ \\
\hline Dichlormethane & $80.12 \pm 6.10$ & $78.35 \pm 6.25$ & $74.96 \pm 6.10$ & $79.00 \pm 6.30$ & $77.12 \pm 6.80$ & $82.25 \pm 6.75$ \\
\hline Dichloromethane/acetone & $86.12 \pm 5.95$ & $87.87 \pm 5.75$ & $86.55 \pm 4.75$ & $90.20 \pm 4.70$ & $90.10 \pm 4.70$ & $89.30 \pm 4.85$ \\
\hline Chloroform $/ n$-hexane & $90.25 \pm 4.00$ & $89.45 \pm 4.10$ & $89.45 \pm 4.10$ & $88.34 \pm 4.25$ & $90.40 \pm 4.40$ & $90.35 \pm 4.25$ \\
\hline
\end{tabular}




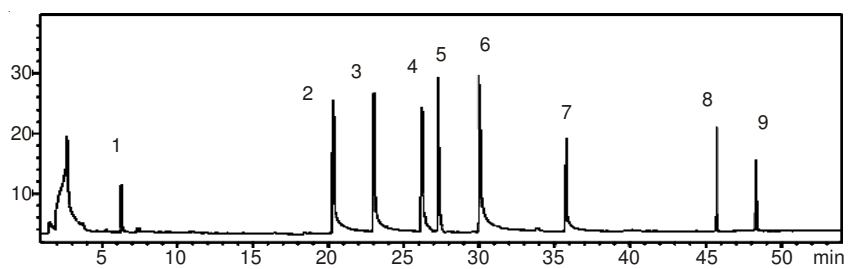

Fig. 1. GC-NPD chromatogram of standard solutions of pesticides 1: dichlorvos; 2: diazinon; 3: parathion-methyl; 4: chlorpyriphos; 5: malathion; 6: methidathion; 7: ethion; 8: cypermethrin; 9: deltamethrin (TRB-5 $30 \mathrm{~m} \times 0.32 \mathrm{~mm}, 0.25 \mathrm{~mm}$ )
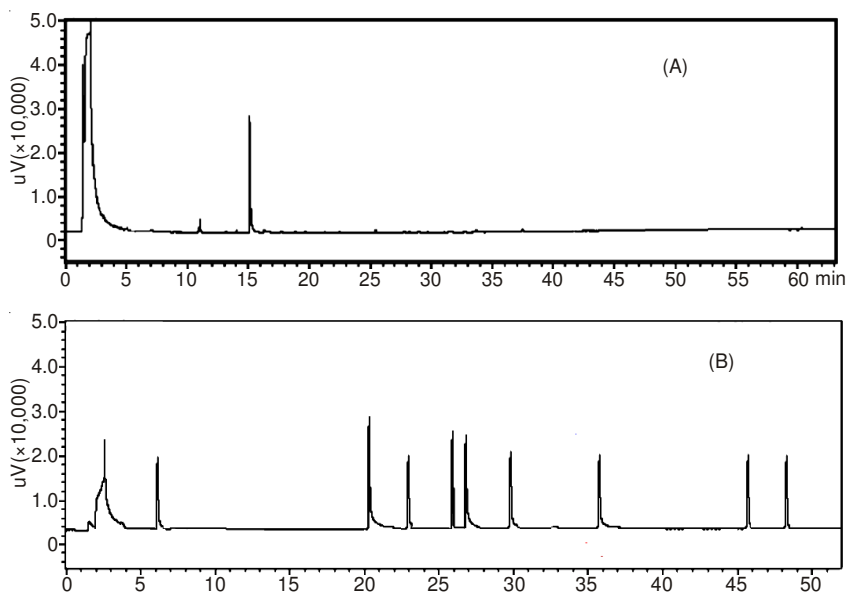

Fig. 2. GC-nitrogen phosphorus detection chromatograms of a) milk sample; b) spiked extracts of milk sample

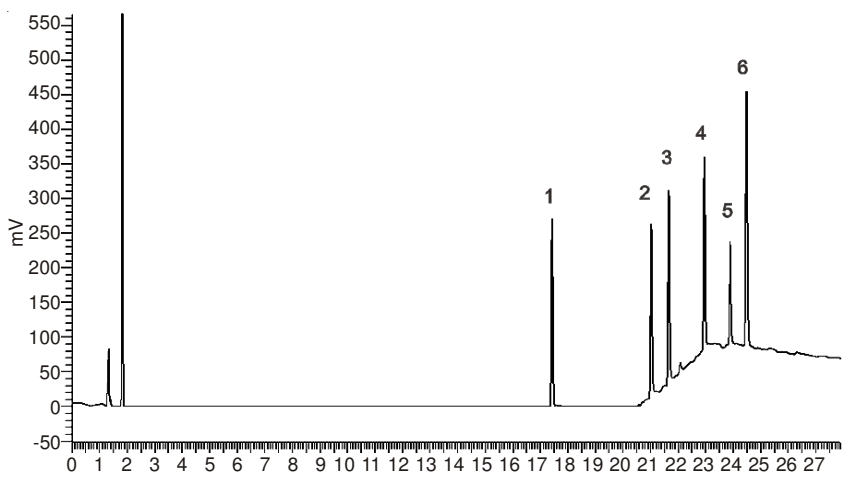

Fig. 3. GC-ECD chromatogram of standard solutions of pesticides $1: \alpha$ endosulfan; 2 : $\beta$-endosulfan; 3: DDE; 4: o,p'-DDT; 5 : DDD; $6: \mathrm{p}, \mathrm{p}^{\prime}-$ DDT $($ PE $17010.30 \mathrm{~m} \times 0.32 \mathrm{~mm}, 1.00 \mathrm{~mm})$
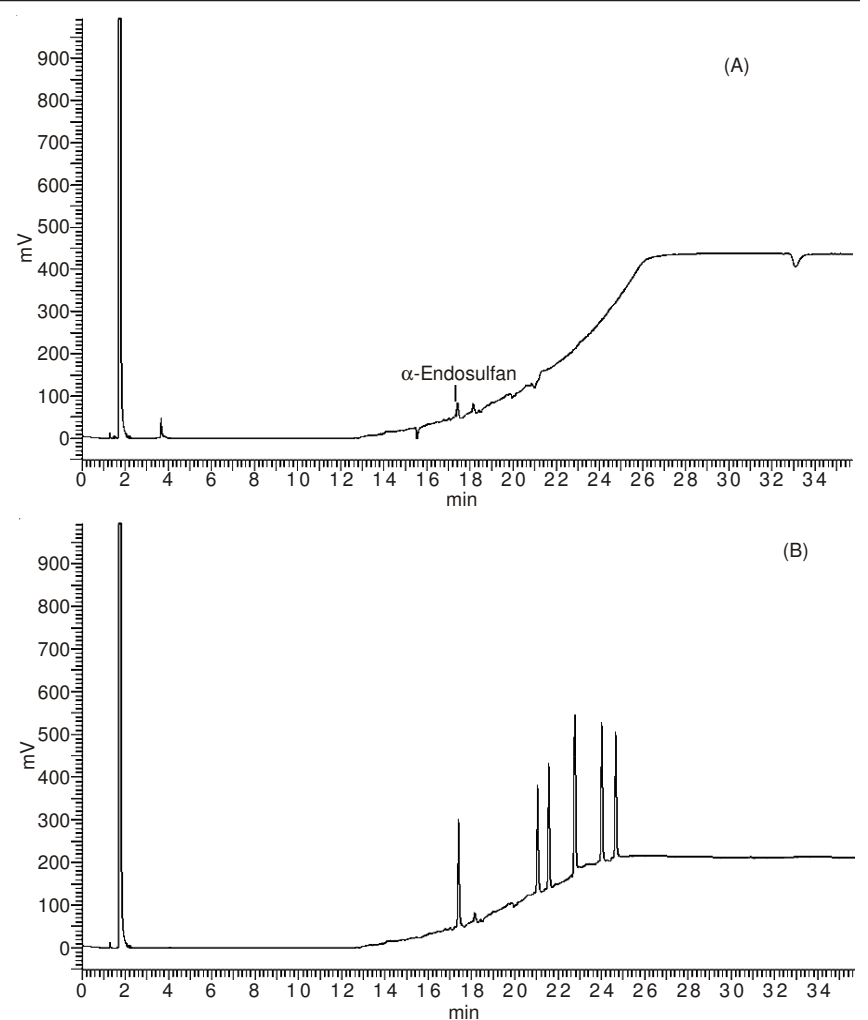

Fig. 4. GC-ECD chromatograms of a: milk sample; b: spiked extracts of milk sample

$p, p^{\prime}$-DDT analyzed by GC-ECD were not find interfering peaks in the areas of interest.

Calibration curves for the studied pesticides were prepared by plotting peak areas $v s$. concentrations for both, nitrogenphosphorous detection and electron-capture detection. Multilevel calibration curves $\left(r^{2}>0.999\right)$ were created for the quantification by using standard solutions in toluene (NPD) and $n$-hexane (ECD). A calibration with six points were established in the method to avoid errors. The repeatability of peak areas and peak retention times were also good with relative standard deviations (RSDs) ranging between 1.0 and $4.05 \%$. Table-4 shows the group, formula, retention time $\left(\mathrm{R}_{\mathrm{t}}\right)$, slope and intercept by GC-NPD/ECD of studied pesticides. The detection limits obtained (signal-to-bottom noise ratio $=3$ ) ranged from

TABLE-4

GROUP, FORMULA, RETENTION TIME, SLOPE AND INTERCEPT FOR BOTH NPD AND ECD

\begin{tabular}{|c|c|c|c|c|c|c|c|}
\hline Compounds & Group & m.f. & $\mathrm{R}_{\mathrm{t}}(\min )$ & Slope & Intercept & $\begin{array}{l}\text { S.E. of } \\
\text { Slope }\end{array}$ & $\begin{array}{c}\text { S.E. of } \\
\text { Intercept }\end{array}$ \\
\hline Diazinone & Organophosphate insecticide & $\mathrm{C}_{12} \mathrm{H}_{21} \mathrm{~N}_{2} \mathrm{O}_{3} \mathrm{PS}$ & 20.5 (NPD) & -0.023 & 2.974 & 0.022 & 0.044 \\
\hline Parathion-methyl & Organophosphate insecticide-acaricide & $\mathrm{C}_{10} \mathrm{H}_{14} \mathrm{NO}_{5} \mathrm{PS}$ & 23.5 (NPD) & 0.015 & 4.465 & 0.020 & 0.013 \\
\hline Methidathion & Organophosphate insecticide & $\mathrm{C}_{6} \mathrm{H}_{11} \mathrm{~N}_{2} \mathrm{O}_{4} \mathrm{PS}_{3}$ & 30.5 (NPD) & -0.028 & 2.879 & 0.031 & 0.009 \\
\hline Ethion & Organophosphate insecticide & $\mathrm{C}_{9} \mathrm{H}_{22} \mathrm{O}_{4} \mathrm{P}_{2} \mathrm{~S}_{4}$ & 36.1 (NPD) & 0.001 & 4.164 & 0.003 & 0.005 \\
\hline Cypermethrin & Pyrethroid ester insecticide & $\mathrm{C}_{22} \mathrm{H}_{19} \mathrm{Cl}_{2} \mathrm{NO}_{3}$ & 45.9 (NPD) & -0.001 & 0.003 & 0.001 & 0.001 \\
\hline Deltamethrin & Pyrethroid ester insecticide & $\mathrm{C}_{22} \mathrm{H}_{19} \mathrm{Br}_{2} \mathrm{NO}_{3}$ & 48.5 (NPD) & -0.025 & 1.011 & 0.003 & 0.009 \\
\hline Dichlorvos & Organophosphate insecticide & $\mathrm{C}_{9} \mathrm{H}_{11} \mathrm{C}_{13} \mathrm{NO}_{3} \mathrm{PS}$ & $5.2(\mathrm{NPD})$ & -0.028 & 2.879 & 0.029 & 0.005 \\
\hline Malathion & Organophosphate insecticide & $\mathrm{C}_{10} \mathrm{H}_{19} \mathrm{O}_{6} \mathrm{PS}_{2}$ & 27.5 (NPD) & 0.021 & 2.425 & 0.019 & 0.007 \\
\hline DDE & Organochlorine pesticide & $\mathrm{C}_{14} \mathrm{H}_{8} \mathrm{Cl}_{14}$ & $21.6(\mathrm{ECD})$ & 0.098 & 5.405 & 0.099 & 0.020 \\
\hline$o, p^{\prime}$-DDT & Organochlorine pesticide & $\mathrm{C}_{14} \mathrm{H}_{9} \mathrm{Cl}_{5}$ & $22.9(\mathrm{ECD})$ & 0.005 & 4.606 & 0.029 & 0.017 \\
\hline DDD & Organochlorine pesticide & $\mathrm{C}_{14} \mathrm{H}_{10} \mathrm{Cl}_{4}$ & $23.8(\mathrm{ECD})$ & 0.047 & 2.422 & 0.036 & 0.008 \\
\hline$p, p^{\prime}$-DDT & Organochlorine pesticide & $\mathrm{C}_{14} \mathrm{H}_{9} \mathrm{Cl}_{5}$ & $24.4(\mathrm{ECD})$ & 0.054 & 8.266 & 0.039 & 0.022 \\
\hline$\alpha$-Endosulfan & Organochlorine pesticide & $\mathrm{C}_{9} \mathrm{H}_{6} \mathrm{Cl}_{6} \mathrm{O}_{3} \mathrm{~S}$ & $17.5(\mathrm{ECD})$ & 0.075 & 8.366 & 0.035 & 0.017 \\
\hline
\end{tabular}


0.004 to $0.027 \mathrm{ng} / \mathrm{g}$ lipid (Table-5). Recoveries obtained from samples spiked at concentration level of $5-10 \mathrm{mg} / \mathrm{L}$ were shown in Table- 2 and Table- 3 . Recoveries of the studied pesticide were in the range from 89.26 to $101.10 \%$.

\begin{tabular}{|c|c|c|c|c|c|}
\hline \multicolumn{6}{|c|}{$\begin{array}{c}\text { TABLE-5 } \\
\text { CORRELATION COEFFICIENTS, LIMITS OF DETECTION } \\
\text { (LOD, S/N = 3.3), LIMITS OF QUANTIFICATION (LOQ, S/N } \\
=10 \text { ), LINEER RANGE AND RSD AS DETERMINED } \\
\text { FOR THE EXTRACTION FROM HUMAN MILK }\end{array}$} \\
\hline Compounds & $r^{2}$ & $\begin{array}{l}\text { LOD } \\
\text { (ng/g } \\
\text { lipid) }\end{array}$ & $\begin{array}{l}\text { LOQ } \\
\text { (ng/g } \\
\text { lipid) }\end{array}$ & $\begin{array}{c}\text { Liner } \\
\text { range } \\
(\mu \mathrm{g} / \mathrm{L})\end{array}$ & $\begin{array}{c}\text { RSD } \\
(\%)\end{array}$ \\
\hline Diazinon & 0.999 & 0.007 & 0.023 & $10-2.00$ & 2.11 \\
\hline Parathion-methyl & 0.999 & 0.014 & 0.046 & $10-2.00$ & 4.03 \\
\hline Methidathion & 0.999 & 0.011 & 0.035 & $10-2.00$ & 2.64 \\
\hline Ethion & 0.999 & 0.009 & 0.030 & $10-2.00$ & 1.95 \\
\hline Cypermethrin & 0.999 & 0.025 & 0.083 & $40-4.00$ & 3.83 \\
\hline Deltamethrin & 0.999 & 0.024 & 0.079 & $40-4.00$ & 1.25 \\
\hline Chlorpyriphos & 0.999 & 0.025 & 0.083 & $10-2.00$ & 1.00 \\
\hline Dichlorvos & 0.999 & 0.027 & 0.089 & $10-2.00$ & 2.64 \\
\hline Malathion & 0.999 & 0.015 & 0.050 & $10-2.00$ & 4.05 \\
\hline DDE & 0.999 & 0.007 & 0.022 & $20-1.00$ & 3.70 \\
\hline$o, p^{\prime}$-DDT & 0.999 & 0.005 & 0.017 & $20-1.00$ & 3.42 \\
\hline DDD & 0.999 & 0.005 & 0.017 & $20-1.00$ & 3.29 \\
\hline$p, p^{\prime}$-DDT & 0.999 & 0.004 & 0.013 & $20-1.00$ & 2.43 \\
\hline$\alpha$-Endosulfan & 0.999 & 0.004 & 0.013 & $20-1.00$ & 3.10 \\
\hline$\beta$-Endosulfan & 0.999 & 0.004 & 0.013 & $20-1.00$ & 3.20 \\
\hline
\end{tabular}

Endosulfan should be measured only in 3 samples while in the other 98 samples the concentration for the sum of organochlorine pesticides was below the detection limit (Table-6). Dichlorvos should be measured only in 5 samples, while in the other samples the concentration for the sum of organophosphorus pesticides was below the detection limit (Table-6).

TABLE-6

OC PESTICIDES AND OP PESTICIDES RESIDUES IN HUMAN MILK SAMPLES OF ISPARTA RESIDENTS (NG/G LIPID)

\begin{tabular}{lcc}
\hline Compounds & Breast milk (mean \pm SD) & Range \\
\hline $\mathrm{N}$ & 101 & \\
Lipid (\%) & 4.10 & \\
Diazinon & $\mathrm{ND}$ & \\
Parathion-methyl & $\mathrm{ND}$ & \\
Methidathion & $\mathrm{ND}$ & \\
Ethion & $\mathrm{ND}$ & \\
Cypermethrin & $\mathrm{ND}$ & \\
Deltamethrin & $\mathrm{ND}$ & \\
Chlorpyriphos & $\mathrm{ND}$ & \\
Dichlorvos & $0.188 \pm 0.041$ & \\
Malathion & $\mathrm{ND}$ & \\
DDE & $\mathrm{ND}$ & \\
$o, p^{\prime}$-DDT & $\mathrm{ND}$ & \\
DDD & $\mathrm{ND}$ & \\
$p, p^{\prime}$-DDT & $\mathrm{ND}$ & \\
$\alpha$-Endosulfan & $0.190 \pm 0.020$ & $(\mathrm{ND}-0.250)$ \\
$\beta$-Endosulfan & $\mathrm{ND}$ & \\
\hline ND: Not detected & &
\end{tabular}

No significant relationship between the human properties and the levels of analyzed organochlorine pesticides and organophosphorus pesticides was found.

Table-7 shows the trend for mean levels of the main organochlorine pesticide residues in human milk from Turkey and
TABLE-7

MEAN LEVELS OF OC PESTICIDES RESSIDUES IN HUMAN MILK FROM DIFFERENT REGIONS OF TURKEY AND VARIOUS COUNTRIES

\begin{tabular}{|c|c|c|c|c|c|c|}
\hline City & Year & $\mathrm{n}$ & $\begin{array}{l}p, p^{\prime}- \\
\text { DDE } \\
\text { (ng/g } \\
\text { lipid) }\end{array}$ & $\begin{array}{l}p, p^{\prime}- \\
\text { DDT } \\
\text { (ng/g } \\
\text { lipid) }\end{array}$ & $\begin{array}{c}\text { DDE/DDT } \\
\text { (ng/g } \\
\text { lipid) }\end{array}$ & Ref. \\
\hline Adana & 1985 & 52 & 1570 & 9690 & 0.16 & 18 \\
\hline Kocaeli & 1985 & 50 & 3370 & 450 & 7.49 & 19 \\
\hline Kayseri & 1989 & 51 & 2390 & 410 & 5.83 & 21 \\
\hline Ankara & 2002 & 101 & 2280 & 130 & 17.67 & 7 \\
\hline Kahramanmaras & 2003 & 37 & 1522 & 60 & 28.00 & 24 \\
\hline Afyon & 2003 & 80 & 2100 & 110 & 19.09 & 25 \\
\hline Antalya & 2007-2008 & 100 & 1060 & 250 & 4.15 & 26 \\
\hline \multicolumn{7}{|l|}{ Country } \\
\hline Russia $^{a}$ & 1996-1997 & 140 & 1192 & 194 & 6.14 & 13 \\
\hline Sweden & 1997 & 40 & 129 & 14 & 9.21 & 27 \\
\hline Mexico & $1997-1998$ & 60 & 3997 & 651 & 6.14 & 28 \\
\hline Japan $^{\mathrm{a}}$ & 1998 & 49 & 270 & 18.0 & 15.0 & 29 \\
\hline China & 1999 & 132 & 2480 & 390 & 6.36 & 30 \\
\hline Czech republic & 2000 & 43 & 979 & 83 & 11.8 & 31 \\
\hline Indonesia $^{a}$ & 2000 & 70 & 285 & 60 & 4.75 & 32 \\
\hline Vietnam & $2000-2001$ & 96 & 2000 & 265 & 7.55 & 33 \\
\hline United Kingdom & 2001-2003 & 54 & 150 & 6.20 & 24.20 & 34 \\
\hline Taiwan $^{\mathrm{a}}$ & $2000-2001$ & 30 & 301 & 22 & 13.70 & 35 \\
\hline Poland & $2000-2001$ & 14 & 1114 & 76.6 & 14.54 & 36 \\
\hline $\operatorname{Iran}^{\mathrm{a}}$ & 2007 & 14 & 1325 & 420 & 3.15 & 14 \\
\hline
\end{tabular}

${ }^{\text {aPrimipara mothers }}$

different countries. There is no available data in the literature about the organophosphorus pesticides residue in human milk from Turkey. There are few papers providing evidence of human exposure by reporting organophosphorus pesticides contamination levels in human milk from the other countries ${ }^{17}$. In India, Sanghi et al. ${ }^{17}$ found $0.043 \mathrm{mg} / \mathrm{L}$ malathion, 0.230 $\mathrm{mg} / \mathrm{L}$ chlorpyriphos and $0.001 \mathrm{mg} / \mathrm{L}$ methyl-parathion residues in human milk samples. There is no available data in the literature about the dichlorvos residue in human milk from Turkey. Because dichlorvos is a fast decaying pesticide. But in Turkey, dichlorvos is being used in many areas. Dichlorvos residues in milk has the hands of people.

In Turkey, Karakaya et al. ${ }^{18}$ found $1570 \mathrm{ng} / \mathrm{g}$ lipid DDE and $9690 \mathrm{ng} / \mathrm{g}$ lipid DDT residues in breast milk samples in 1985. Erdogrul et al. ${ }^{24}$ also investigated 37 milk samples for organohalogenated persistent pollutants. They found $1522 \mathrm{ng} /$ $\mathrm{g}$ lipid DDE and $60 \mathrm{ng} / \mathrm{g}$ lipid DDT residues in breast milk samples in 2003. Cok et al. ${ }^{26}$ analyzed 100 human samples from Antalya (2007-2008), determining $1060 \mathrm{ng} / \mathrm{g}$ lipid DDE and $250 \mathrm{ng} / \mathrm{g}$ lipid DDT residues in breast milk samples. In this study, no residues of DDE, DDD, o,p'-DDT and p,p'-DDT were found in 101 human milk samples. In the early 1980 's, high levels of p,p'-DDT and DDE were detected in human milk collected from different cities in Turkey. But a sharp decrease was appeared in the levels of DDTs in human milk. Since the 1970s, the usage of organochlorine pesticide was banned.

In Turkey, only usage of endosulfan for agricultural purposes was prohibited in 2007. Cok et al. ${ }^{26}$ analyzed 100 human samples from Antalya (2007-2008), determining $2 \mathrm{ng} / \mathrm{g}$ lipid $\alpha$-endosulfan residues in breast milk samples. In this study, value of endosulfan was found $0.190 \mathrm{ng} / \mathrm{g}$ lipid $\alpha$-endosulfan. The decreases in concentration of endosulfan probably continuing prohihibitions on the use of endosulfan. 
In Russia, Polder et al. ${ }^{11}$ found $1192 \mathrm{ng} / \mathrm{g}$ lipid DDE and $194 \mathrm{ng} / \mathrm{g}$ lipid DDT residues in breast milk samples between 1996-1997. Minh et al. ${ }^{33}$ investigated 52 milk samples for organochlorine pesticides. They found $2000 \mathrm{ng} / \mathrm{g}$ lipid DDE and $265 \mathrm{ng} / \mathrm{g}$ lipid DDT residues in breast milk samples in Hochiminh (Vietnam) between 2000-2001. Dahmardeh Behrooz et al. ${ }^{14}$ analyzed 14 human samples in 2007 from Tabriz (Iran), determining $1325 \mathrm{ng} / \mathrm{g}$ lipid DDE and $420 \mathrm{ng} / \mathrm{g}$ lipid DDT residues in breast milk samples.

This paper describes an analytical, simple and reproducible method for determining residues of pesticides in different milk samples. No additional clean up was necessary, because chromatograms of samples are free from interfering peaks. The recoveries obtained using samples spiked with a standard pesticides mixture range from 89.26 to $101.10 \%$. The method showed recoveries and repeatabilities. RSDs ranged from 1.0 to $4.05 \%$. The detection limits obtained ranged from 0.004 to $0.027 \mathrm{ng} / \mathrm{g}$ lipid (Table-5). These values are in general, in agreement to those determined in human milk by Erdogrul et al. ${ }^{24}$.

\section{Conclusion}

Results from this study showed that the amount of selected organochlorine and organophosphorus pesticide in human milk in Isparta. The presence of pesticides in human milk is of general interest because of the potential health effect of these chemicals.

\section{REFERENCES}

1. M.J. Melgar, M. Santaeufemia and M.A. Garcìa, J. Environ. Sci. Health $B, 45,595$ (2010).

2. A. Blair and S.H. Zahm, Environ. Health Persp., 103, 205 (1995).

3. J.F. Viel and B. Challier, Occup. Environ. Med., 52, 587 (1995).

4. W.W. Au, C.H. Sierra-Torres, N. Cajas-Salazar, B.K. Shipp and M.S. Legator, Environ. Health Persp., 107, 501 (1999).

5. S. Pastor, S. Gutiérrez, A. Creus, A. Cebulska-Wasilewsk and R. Marcos, Mutat. Res., 495, 147 (2001).

6. J.H. Salas, M.M. Gonzàlez, M. Noa, N.A. Pérez, G. Dìaz, R. Gutièrrez, H. Zazueta and I. Osuna, J. Agric. Food Chem., 51, 4468 (2003).

7. I. Çok, M.K. Donmez and A.E. Karakaya, Environ. Contam. Toxicol., 72, 522 (2004).

8. G. Pagliuca, T. Gazzotti, E. Zironi and P. Sticca, J. Chromatogr. A, 1071, 67 (2005).

9. G. Pagliuca, A. Serraino, T. Gazzotti, E. Zironi, A. Borsari and R. Rosmini, J. Dairy Res., 73, 340 (2006).

10. R. Kobata, H. Tsukahara, Y. Ohshima, N. Ohta, S. Tokuriki, S. Tamura and M. Mayumi, Early Hum. Dev., 84, 67 (2008).
11. C. Polder, G. Thomsen, K.B. Lindström, J.U. Løken and A. Skaare, Chemosphere, 73, 14 (2003).

12. C. Campoy, M. Jiménez, M.F. Olea-Serrano, M. Moreno Frías, F. Canabate, N. Olea, R. Bayés and J.A. Molina-Font, Early Hum. Dev., 65, 183 (2001).

13. A. Polder, J.O. Odland, A. Tkachev, S. Føreid, T.N. Savinova and J.U. Skaare, Sci. Total Environ., 306, 179 (2003).

14. R.D. Behrooz, A.E. Sari, N. Bahramifar and S.M. Ghasempouri, Chemosphere, 74, 931 (2009).

15. Y. Pico, E. Viana, G. Font and J. Manes, J. Agric. Food Chem., 43, 1610 (1995).

16. A. Covaci, C. Hura and R. Schepens, Chromatographia, 54, 247 (2001).

17. R. Sanghi, M.K.K. Pillai, T.R. Jayalekshmi and A. Nair, Hum. Exp. Toxicol., 22, 73 (2003).

18. A.E. Karakaya and S. Özalp, Bull. Environ. Contam. Toxicol, 38, 941 (1987).

19. A.E. Karakaya, S. Burgaz and I. Kanzik, Bull. Environ. Contam. Toxicol., 39, 506 (1987).

20. S. Burgaz, B.L. Afkham and A.E. Karakaya, Bull. Environ. Contam. Toxicol., 53, 501 (1994).

21. H.B. Ustunbas, M.A. Öztürk, E. Hasanoglu and M. Dogan, Hum. Exp. Toxicol., 13, 299 (1994).

22. I. Çok, A. Bilgili, M. Özdemir, H. Özbek, N. Bilgili and S. Burgaz, Bull. Environ. Contam. Toxicol., 59, 577 (1997).

23. I. Çok, A. Bilgili, E. Yarsan, C. Bagci and S. Burgaz, Bull. Environ. Contam. Toxicol., 61, 311 (1998).

24. Ö. Erdogrul, A. Covaci, N. Kurtul and P. Schepens, Environ. Int., 30, 659 (2004).

25. I. Çok, D. Toprak, T.C. Durmaz, E. Demirkaya and C. Kabukçu, Fresenius Environ. Bull., 14, 503 (2005).

26. I. Çok, Ç. Yelken, E. Durmaz, M. Üner, B. Sever and F. Satir, Bull. Environ. Contam. Toxicol., 86, 423 (2011).

27. K. Norén and D. Meironyté, Chemosphere, 40, 1111 (2000).

28. S.M. Waliszewski, A.A. Aguirre, R.M. Infanzon, A. Benitez and J. Rivera, Bull. Environ. Contam. Toxicol., 64, 8 (1999).

29. Y. Konishi, K. Kuwabara and S. Hori, Arch. Environ. Contam. Toxicol., 40, 571 (2001).

30. C.K. Wong, K.M. Leung, B.H. Poon, C.Y. Lan and M.H. Wong, Arch. Environ. Contam. Toxicol., 43, 364 (2002).

31. T. Cajka and J. Hajšlová, Bull. Environ. Contam. Toxicol., 70, 913 (2003).

32. E.R. Burke, A.J. Holden, I.C. Shaw, F.X. Suharyanto and G. Sihombing, Bull. Environ. Contam. Toxicol., 71, 148 (2003).

33. N.H. Minh, M. Someya, T.B. Minh, T. Kunisue, H. Iwata, M. Watanabe, S. Tanabe, P.H. Viet and B.C. Tuyen, Environ. Pollut., 129, 431 (2004).

34. O.I. Kalantzi, F.L. Martin, G.O. Thomas, R.E. Alcock, H.R. Tang, S.C. Drury, P.L. Carmichael, J.K. Nicholson and K.C. Jones, Environ. Health Persp., 112, 1085 (2004).

35. H.R. Chao, S.L. Wang, T.C. Lin and X.H. Chung, Chemosphere, 62, 1774 (2006).

36. K. Szyrwinska and J. Lulek, Chemosphere, 66, 1895 (2007). 